319

LMBILICAL SERUM CORTISOL (F), DEHYDROEPIANDPCSTERONE SULFATE (DHAS) AND TOTAL ESTRIOL $\left(E_{3}\right)$ LEVELS IN PRE MATURE AND FULL TERM INFANTS. Akihiko Noguchi, Marvin R. Turnipseed, Karen Bentley and John $w$. Reynolds. University of Minnesota Medical School, Department of Pediatrics.

Neonatal interrelationships of $F$, DHAS and $E_{3}$ in cord blood in reference to gestational age and mode of delivery were exmined. Cord serum steriods were determined by radioimmunoassay in 275 vaginally delivered infants (30-42 wks gestation) and $20 \mathrm{C}$-section infants (36-42 wks). In the vaginally born group hean $\mathrm{E}_{3} 1832+744$ (SD) $\mathrm{ng} / \mathrm{ml}$ of $36-42$ wks infants was higher than $1276+46 \overline{0}$ of $30-35$ wks infants. $(t, p<0.005)$. The corresponding DHAS levels were $2301 \pm 737 \mathrm{ng} / \mathrm{ml}$ and $2216+781$ respectively $(\mathrm{p}>.05) ; \mathrm{F}$ levels were $15 \overline{3}+67 \mathrm{ng} / \mathrm{ml}$ and $123+\overline{5} 5$ respectively $(p>05)$. F and DHAS level $\bar{s}$ were higher in vaginally born than -section infants, $(p<0.005)$, but not for $\mathbf{E}_{3}$. In each group, $F$, PHAS and $E_{3}$ levels were similar regardless of spontaneous onset pr absence of labor. Thus, after 35 wks gestation, fetal serum estriol levels increase without corresponding increase in DHAS Fetal cortisol and DHAS are increased with vaginal delivery. ve speculate that after 35 wks the fetal adrenal gland increases ts production of DHAS which is efficiently coverted to estriol y the placenta; the acute stress of vaginal delivery increases etal cortisol as well as DHAS production.

320 EFFECT OF IN-UTERO INTRAVENOUS ADIINISTRATION OF THYROXINE AND OTHER HORMONES ON LUNG FLUID LECITHIN SPHINGOMYELIN (L/S) RATIO OF THE FETAL LAMB. Uchenna C. Nwosu, James D. Ferguson, Edward E. Wallach, Alfred M. Bonglovanni and Maria Delivoria-Papadopoulos. Univ. of Pennsylvania Sch. of Med., Dept. of Ped., and Pennsylvania Hosp., Dept. of Ob-Gyn. Philadelphia, Pa.

Glucocorticoid hormones influence lung maturation, but their effect on the L/S ratio has not been clearly demonstrated. Prior to lung maturity 9 fetal lambs (mean 118 days) were chronically catheterized in-utero. Fetal lung fluid was diverted into an external drainage bag by a Foley catheter through a tracheotomy. A single dose of Cortisol 2.5-5.0 mg., Dexamethasone 200/ $\mathrm{ng}, \mathrm{T} 4500 / \mathrm{ng}$, or T3 $1-150 / \mathrm{ng}$ was administered via the jugular catheter for 3 days during the first treatment period beginning 3-12 days after surgery. An identical course of treatment was repeated 10 days later. Fetal blood $\mathrm{pH}$ and plasma level of the administered hormone were monitored daily. The $\mathrm{L} / \mathrm{S}$ profile for each fetal lamb was compared to a mean curve derived from 7 control fetal lambs recelving saline solution at comparable periods No change in the lung fluid L/S pattern was found after repeated administration of Cortisol or Dexamethasone in 3 fetal lambs. A sharp increase in the ratio was seen after 2 courses of T4 treat ment in 2 fetal lambs while T4 treatment during the second period alone failed to produce this effect. Administration of 1-10/ ng of $\mathrm{T} 3$ during the second period alone produced no change in the $\mathrm{L} / \mathrm{S}$ ratio in the 3 remaining lambs. These preliminary data suggest that pharmacological doses of T4 can alter the lung fluid $\mathrm{L} / \mathrm{S}$ ratio in fetuses previously primed with that hormone.

\section{PRENATAL SURGE OF PLASMA T3 IN THE FETAL LAMB}

321 Uchenna C. Nwosu, Michael M. Kaplan, Endla K. Anday, of Med., Depts. of Med. and Ped., and Pennsylvania vania Sch. of Med., Depts. of Med. and Ped.,

Prenatal changes in iodothyronine levels with respect to parturition have not been clearly established. The present studie investigate the changes of fetal serum iodothyronine concentration preceeding labor. Seven fetal lambs 113-135 days gestation were chronically catheterized in-utero from early 3rd trimester to delivery. Daily plasma concentrations of Cortiso1, T4, T3, and $\mathrm{rT} 3$ were measured. Simultaneous maternal blood samples wer simflarly analyzed. Mean fetal plasma T3 rose from a baseline of $30 \mathrm{ng} / \mathrm{d} 1$ to $150 \mathrm{ng} / \mathrm{d} 1$ one day prior to delivery with most of the increase occurring during the 4 days prior to labor. Fetal plasma Cortisol was found to increase in phase with T3. Mean Cortisol rose in the 4 days prior to labor from a baseline of 1 $\mathrm{ng} / \mathrm{dl}$ to $8 \mathrm{ng} / \mathrm{d} 1$ and sharply increased 1 day prior to delivery. Mean values for fetal plasma T4 and rT3 were $12 \mathrm{ng} / \mathrm{dl}$ and 450 $\mathrm{ng} / \mathrm{dl}$ respectively, and although no significant changes occurred a tendency to decrease was evident during the 10 days prior to delivery. Fetal and maternal hormone levels were independent at all times. Baseline maternal $\mathrm{T} 3$ and Cortisol were 2 times higher than fetal levels until the 4 days prior to delivery when fetal levels rose to 4 and 2 times the maternal levels respective1y. Mean maternal T4 and $\mathrm{rT} 3$ levels remained $\frac{1}{2}$ and $\frac{1}{4}$ of the mean fetal values. The abrupt increase in fetal $\mathrm{T} 3$ without a corresponding change in T4 suggests the basic alteration is in ex-
trathyroidal 44 to T3 conversion, not in increased TSH secretion.
322 USEFULNESS OF PLA SMA ANDROGEN CONCENTRA TIONS FOR THE DIAGNOSIS OF VIRILIZING CONGENITAL ADRENAL HYPERPLASIA (VCAH) IN NEONA TES AND YOUNG INFANTS. S. Pang, L.S. Levine D. M. Chow and M. I. New, Cornell Univ. Med. Col. , New York Plasma androgen concentrations, androstenedione, dehydroepiandrosterone (DHEA), testosterone ( $T$ ) were measured in cord blood and from birth to 1 year-of-age in normal infants and in 4 male and 4 female infants ultimately proven to have VCAH. Cord blood androgen concentrations in two affected males did not differ from those of normal newborns (12 female, 16 males). Androstenedione in all affected infants was highly elevated while DHEA was elevated in only 3 infants. T was clearly elevated in all affected females. However, since the normal newborn male has high $T$ concentrations $(25-428)$, $T$ concentrations in male infants with VCAH (60-295) were indistinguishable from normal. $T$ in these infants decreased with glucocorticoid administration (blank-11) suggesting that the $T$ was adrenal in origin and that testicular testosterone was suppressed in the untreated state. Conclusions: 1) cord blood endrogen concentrations may not be diagnostic for VCAH; 2) lasma androstenedione is clearly a diagnostic hormone for VCAH in both sexes while $\mathrm{T}$ is useful only in female infants: and 3) the evidence of suppressed Leydig cell function in affected males suggests presence of negative feedback of the gonadtat in young male infants by excess adrenal steroids.

323

Abstract withdrawn
324

TRI-IODOTHYRONINE ( $\left.T_{3}\right)$ ELEVATION DUE TO DESICCATED THYROID. Robert Penny and S. Douglas Frasier. University of Southern California School of Medicine, and Los Angeles County-USC Medical Center, Department of Pediatrics, Los Angeles, Cal ifornia.

Fourteen hypothyroid children, 10 girls and 4 boys, had serum $\mathrm{T}_{4}, \mathrm{~T}_{3}$ and TSH measured while receiving replacement therapy with desiccated thyroid and 6 weeks after beginning replacement therapy with sodium- $\ell$-thyroxine, $4.2 \pm 0.6(\mathrm{SD}) \mu \mathrm{g} / \mathrm{kg}$ per day (maximum $200 \mu \mathrm{g}$ ). Serum $\mathrm{T}_{3}$ while receiving desiccated thyroid was $393 \pm 144$ (SD) $\mathrm{ng} / \mathrm{dl}$ compared to $157 \pm 23$ (SD) $\mathrm{ng} / \mathrm{dl}$ while receiving thyroxine $(P<0.01)$. Serum $T_{3}$ exceeded $220 \mathrm{ng} / \mathrm{dl}$ in 13 patients on desiccated thyroid. All serum $T_{3}$ concentrations were within the normal range on thyroxine. Therapy with both thyroid and thyroxine resulted in normal $\mathrm{T}_{4}$ and TSH concentrations. However, the mean T4 concentration on desiccated thyroid was $7.4 \pm 2.0$ (SD) $\mu \mathrm{g} / \mathrm{dl}$ compared to $11.7 \pm 2.5(\mathrm{SD}) \mu \mathrm{g} / \mathrm{dl}$ while receiving thyroxine $(\mathrm{P}<0.01)$. Mean TSH concentration was $1.3 \pm 1.2(\mathrm{SD}) \mu \mathrm{U} / \mathrm{ml}$ on thyroid and $1.6 \pm 1.1(\mathrm{SD})$ $\mu \mathrm{U} / \mathrm{ml}$ on thyroxine $(\mathrm{P}>0.1)$. Our findings show that a paradoxically elevated serum $T_{3}$ concentration, unassociated with clinical hyperthyroidism is, in general, characteristic of treatment with desiccated thyroid. Replacement with sodium- $\ell$-thyroxine leads to normalization of all routine tests of thyroid function. 